\title{
Pengetahuan, Persepsi dan Sikap Generasi Muda Tentang Perubahan Iklim dan Pengaruhnya Terhadap Niat Perilaku Pro-Lingkungan Dian Harmuningsih ${ }^{1}$, Saul Ronald Jacob Saleky ${ }^{2}$ \\ ${ }^{1}$ Pramuka Peduli Kwartir Daerah Gerakan Pramuka Jawa Timur, Surabaya. Email: achen_java@yahoo.com \\ ${ }^{2}$ Puslitbang Kwartir Daerah Gerakan Pramuka Maluku, Ambon. Email: saulsaleky@ gmail.com
}

\begin{abstract}
Climate change continues to occur and have an impact for the survival of mankind. Climate change is not only a natural phenomenon, but also includes contributions from the behavior of the human. Hence need for awareness and goodwill of all parties, especially the young generation, to reduce the impact of climate change. This study aimed to analyze the influence of factors of knowledge, perception and attitude towards pro-environmental behavior intention of the young generation. By using multiple regression analysis, the results of this study show that the factor of knowledge, perceptions and attitudes about climate change have a positive influence and significant to pro-environmental behavior intention of the young generation. Furthermore, of these factors, the perceptions of the climate change are factors that have a more dominant influence on the intention proenvironmental behavior of the young generation. Thus, in order to further grow and develop the intention of young people to behave in a pro-environment, for they need to be given opportunities and greater access to resources and information channels to increase their knowledge related to environmental strategic issues, especially climate change and its impacts, so with the knowledge that will shape their perceptions better on climate change and, in turn, will form a more empathetic attitude. For that, the one way can be used is to empower organizations where they are working as a means to increase knowledge, shape perceptions and attitudes and arouse their intentions to behave pro-environment, through the activity of an organized, planned and organized.
\end{abstract}

Keywords: Climate Change, Knowledge, Perception, Attitude, Behavior Intention

\begin{abstract}
Abstrak
Perubahan iklim terus terjadi dengan menimbulkan dampak bagi kelangsungan hidup umat manusia. Perubahan iklim bukan hanya merupakan fenomena alam, namun juga mencakup kontribusi dari perilaku hidup umat manusia. Oleh karena itu perlu adanya kesadaran dan niat baik dari semua pihak, terutama generasi muda, untuk mengurangi dampak dari perubahan iklim. Penelitian ini bertujuan untuk menganalisis pengaruh dari faktor pengetahuan, persepsi dan sikap terhadap niat perilaku pro-lingkungan dari generasi muda. Dengan menggunakan analisis regresi berganda, hasil penelitian ini menunjukan bahwa faktor pengetahuan, persepsi dan sikap tentang perubahan iklim memiliki pengaruh yang positif dan signifikan terhadap niat perilaku prolingkungan dari generasi muda. Selanjutnya, dari ketiga faktor tersebut, persepsi tentang perubahan iklim merupakan faktor yang memiliki pengaruh lebih dominan terhadap niat perilaku pro-lingkungan dari generasi muda. Dengan demikian, guna lebih menumbuh-kembangkan niat generasi muda untuk berperilaku yang prolingkungan, bagi mereka perlu diberikan kesempatan dan akses yang lebih luas terhadap sumber dan jalur informasi untuk menambah pengetahuan terkait isu-isu lingkungan yang strategis, terutama perubahan iklim dan dampaknya, sehingga dengan pengetahuan tersebut akan membentuk persepsi mereka yang lebih baik tentang perubahan iklim dan pada gilirannya akan membentuk sikap yang lebih berempati terhadap perubahan iklim. Untuk itu, salah satu cara yang dapat digunakan adalah dengan memberdayakan organisasi tempat mereka berkecimpung sebagai sarana untuk menambah pengetahuan, membentuk persepsi dan sikap serta menggugah niat mereka untuk berperilaku yang pro-lingkungan, melalui akivitas yang teratur, terarah dan terencana.
\end{abstract}

Kata Kunci: Perubahan Iklim, Pengetahuan, Persepsi, Sikap, Niat Perilaku.

\section{Pendahuluan}

Sejak akhir tahun 1960-an, perhatian masyarakat terhadap pencemaran lingkungan dan kerusakan lingkungan memuncak (Djajaningrat dkk, 2014). Pertimbangan tentang faktor lingkungan makin 
menjadi tantangan dalam berbagai bidang kehidupan manusia - ekonomi, sosial, budaya, dan politik yakni bagaimana memenuhi kebutuhan generasi masa kini tanpa harus menurunkan kesempatan yang sama dari generasi mendatang. Oleh karena itu kepedulian terhadap lingkungan bukan merupakan isu tunggal.

Perubahan iklim adalah perubahan jangka panjang dalam distribusi pola cuaca secara statistik sepanjang periode waktu mulai dasawarsa hingga jutaan tahun. Perubahan iklim bisa juga berarti perubahan keadaan cuaca rata-rata atau perubahan distribusi peristiwa cuaca rata-rata, contohnya, jumlah peristiwa cuaca ekstrem yang semakin banyak atau sedikit. Perubahan iklim terbatas hingga regional tertentu atau dapat terjadi di seluruh wilayah Bumi (Wikipedia, 2016).

Untuk itu, guna menjawab tantangan pembangunan sekaligus tetap mempertahankan kualitas lingkungan -termasuk akibat perubahan iklim-, diperlukan adanya kebijakan pengelolaan lingkungan yang terpadu. Kebijakan tersebut tidak cukup hanya melalui pendekatan peraturan perundangan saja, melainkan perlu didukung oleh pendekatan sukarela. Pendekatan sukarela mengandung pengertian bahwa pengelolaan lingkungan melibatkan peranserta berbagai pihak, pemerintah, dunia usaha, lembaga swadaya dan organisasi masyarakat, dan lain sebagainya.

Generasi muda sebagai bagian dari masyarakat memiliki potensi yang luar biasa untuk terlibat dalam kepedulian lingkungan. Keterlibatan generasi muda dalam masalah lingkungan secara global karena mereka siap untuk memecahkan banyak masalah, dan cenderung memiliki sikap yang lebih menguntungkan terhadap lingkungan (Diamantopaoulus dkk, 2003). Selain itu, mereka cenderung lebih peduli tentang kualitas lingkungan dari orang tua (Pauw dan Van Pategem, 2010). Di samping itu, generasi muda juga bersedia untuk berkorban secara ekonomi untuk lingkungan yang lebih baik (Wesley, 2011).

Keterlibatan generasi muda tersebut dapat diwujudkan dalam bentuk kegiatan-kegiatan konseptual dan operasional terkait dengan isu lingkungan. Untuk mendukung keterlibatan itu, dibutuhkan adanya pengetahuan, persepsi dan sikap. Pengetahuan merupakan hasil dari tahu dan ini terjadi setelah orang melakukan penginderaan suatu obyek tertentu (Ancok, 1997). Penginderaan terjadi melalui panca indera manusia yakni indera penglihatan, pendengaran, penciuman, rasa dan raba. Pengetahuan muncul ketika seseorang menggunakan indra atau akal budinya untuk mengenali benda atau kejadian tertentu yang belum pernah dilihat atau dirasakan sebelumnya, misalnya ketika seseorang mencicipi masakan yang baru dikenalnya, ia akan mendapatkan pengetahuan tentang bentuk, rasa, dan aroma masakan tersebut. Sikap seseorang terhadap suatu obyek adalah perasaan mendukung atau memihak (favorable) ataupun perasaan tidak mendukung (unfavorable) terhadap objek tersebut (Notoatmodjo, 2003). Sikap merupakan penilaian yang positif atau negatif tentang sistem yang mempengaruhi perasaan emosi yang menghubungkan respon terhadap objek sosial (Azwar, 2008).

Perilaku merupakan suatu kegiatan atau aktivitas organisme yang bersangkutan. Jadi pada hakikatnya perilaku manusia adalah suatu aktivitas daripada manusia itu sendiri. Oleh sebab itu, perilaku manusia itu mempunyai bentangan yang sangat luas, mencakup berjalan, berbicara, bereaksi, berpakaian, dan lain-lain. Bahkan kegiatan internal seperti berpikir, persepsi, dan emosi juga merupakan perilaku manusia (Purwanto, 1998).

Dengan demikian, dapat dikatakan bahwa pengetahuan merupakan tahap awal terjadinya persepsi yang kemudian melahirkan sikap dan pada gilirannya melahirkan perbuatan atau tindakan. Melalui pengetahuan yang baik tentang suatu hal, akan mendorong terjadinya perubahan perilaku dan menyebabkan seseorang bersikap positif terhadap hal tersebut (Notoatmodjojo, 2005). Niat untuk ikut serta dalam suatu kegiatan, sangat tergantung pada apakah seseorang mempunyai sikap positif terhadap kegiatan itu. Adanya niat yang sungguh-sungguh untuk melakukan suatu kegiatan akhirnya dapat menentukan apakah kegiatan itu betul-betul dilakukan.

Penelitian ini mengadopsi teori Planned Behavior yang merupakan turunan dari teori Reasoned Action yang dikembangkan oleh Azjen (Azjen, 1988) serta teori perilaku konsumen yang dikembangkan oleh 
Schifman dan Kanuk (2000). Dalam konteks penelitian ini, pengetahuan, persepsi dan sikap generasi muda dikaitkan dengan isu perubahan iklim yang dalam beberapa tahun terakhir ini telah menjadi isu utama dalam berbagai pertemuan di berbagai tingkatan. Terminologi generasi muda yang digunakan dalam penelitian ini adalah mereka yang berada pada kelompok usia 15 - 35 tahun.

Penelitian ini bertujuan untuk melakukan pengujian kausalitas dari pengetahuan, persepsi dan sikap generasi muda tentang perubahan iklim terhadap niat perilaku pro-lingkungan, yang meliputi :

a. Menguji pengaruh pengetahuan generasi muda tentang perubahan iklim terhadap niat perilaku pro-lingkungan.

b. Menguji pengaruh persepsi generasi muda tentang perubahan iklim terhadap niat perilaku prolingkungan.

c. Menguji pengaruh sikap generasi muda terhadap perubahan iklim terhadap niat perilaku prolingkungan.

d. Mengidentifikasi variabel manakah di antara pengetahuan, persepsi dan sikap generasi muda tentang perubahan iklim yang lebih dominan terhadap niat perilaku pro-lingkungan.

Oleh karena itu, berdasarkan uraian di atas, hipotesis yang akan diuji dalam penelitian ini adalah sebagai berikut :

H1 Pengetahuan tentang perubahan iklim berpengaruh positif dan signifikan terhadap niat perilaku pro-lingkungan dari generasi muda

H2 Persepsi tentang perubahan iklim berpengaruh positif dan signifikan terhadap niat perilaku pro-lingkungan dari generasi muda

H3 Sikap terhadap perubahan iklim berpengaruh positif dan signifikan terhadap niat perilaku prolingkungan dari generasi muda

H4 Dari faktor pengetahuan, persepsi dan sikap tentang perubahan iklim, faktor yang paling dominan berpengaruh terhadap niat perilaku pro-lingkungan dari generasi muda adalah persepsi tentang perubahan iklim

\section{Metode}

Penelitian ini adalah penelitian kuantitatif yang melakukan pengujian pengaruh antar variabel. Variabel yang digunakan dalam penulisan ini adalah variabel bebas dan variabel terikat. Variabel bebas (independent variable), yaitu Pengetahuan tentang Perubahan Iklim, adalah pengetahuan yang dimiliki generasi muda tentang perubahan iklim dan dampaknya bagi kehidupan manusia. Selanjutnya variabel Persepsi tentang Perubahan Iklim, adalah pandangan generasi muda terhadap perubahan iklim dan dampaknya bagi kelangsungan hidup umat manusia. Serta variabel Sikap terhadap Perubahan Iklim, yaitu sikap generasi muda terhadap perubahan iklim dan dampaknya bagi kelangsungan hidup umat manusia. Variabel terikat (dependent variabel), adalah Niat Perilaku Pro-Lingkungan, yaitu keinginan atau niat generasi muda untuk menunjukan perilaku yang berpihak kepada lingkungan di sekitarnya.

Data penelitian ini dikumpulkan melalui kuesioner yang didistribusikan secara offline dan online. Responden penelitian ini adalah generasi muda yang berusia antara 15 - 35 tahun. Kuesioner penelitian ini dikembangkan menggunakan Skala Likert dengan rentang alternatif jawaban antara 1 sampai dengan 5. Angka 1 menunjukan respon Sangat Tidak Setuju, angka 2 menunjukan respon Tidak Setuju, angka 3 menunjukan respon Netral, angka 4 menunjukan respon Setuju dan angka 5 menunjukan respon Sangat Setuju atas pernyataan-pernyataan yang diberikan.

Untuk dapat mengukur besarnya nilai dari suatu variabel yang ingin diteliti, diperlukan alat ukur berupa skala atau tes yang berkualitas, agar kesimpulan penelitian nantinya tidak keliru dan tidak memberikan gambaran yang jauh berbeda dengan keadaan yang sebenarnya. Pengujian kualitas data penelitian ini dilakukan dalam bentuk pengujian validitas, pengujian reliabilitas dan pengujian asumsi klasik.

Validitas adalah sejauh mana ketepatan dan kecermatan suatu alat ukur dalam melakukan fungsi ukurnya. Valid tidaknya suatu alat ukur tergantung pada kemampuan alat tersebut untuk mengukur 
objek yang diukur dengan cermat dan tepat. Dalam penelitian ini dilakukan pengujian validitas terhadap item pernyataan yang digunakan. Keputusan pada sebuah butir pertanyaan dapat dianggap valid, dilakukan dengan membandingkan nilai sig. < nilai koefisien korelasi Spearman > 0,377 (Suliyanto, 2011).

Uji reliabilitas dilakukan dengan maksud untuk menguji sejauh mana hasil suatu pengukuran dapat dipercaya. Jika hasil pengukuran yang dilakukan berulang menghasilkan hasil yang relatif sama, pengukuran tersebut dianggap memiliki reliabilitas yang baik. Dalam penelitian ini uji reliabilitas yang dilakukan adalah reliabilitas internal.

Pengujian asumsi klasik dalam menggunakan regresi berganda dimaksudkan untuk mengetahui normalitas sebaran data, ada tidaknya gejala heteroskedastisitas, autokorelasi dan multikolinearitas data yang digunakan dalam penelitian ini. Uji normalitas dilakukan guna mengetahui apakah residual yang diteliti berdistribusi normal atau tidak. Nilai residual berdistribusi normal merupakan suatu kurva berbentuk lonceng (bell-shaped curve) yang kedua sisinya melebar sampai tidak terhingga. Uji heterokedastisitas dimaksudkan untuk menguji ada tidaknya varian variabel dalam model yang tidak sama (konstan). Uji autokorelasi bertujuan untuk mengetahui apakah ada korelas antara anggota serangkaian data observasi yang diuraikan menurut waktu (times series) atau ruang (cross section). Dalam penelitian ini pengujian autokorelasi menggunakan metode durbin-watson. Uji multikolinearitas dimaksudkan untuk mengetahui ada tidaknya korelasi yang mendekati sempurna di antara variabel independen. Untuk mengetahui ada tidaknya multikolinearitas antar variabel independen, cara yang digunakan dalam penelitian ini adalah dengan melihat besarnya nilai variance inflation factor (VIF) dari masing-masing variabel independen terhadap variabel dependen.

Data yang berhasil dikumpulkan selanjutnya diolah dan dianalisis menggunakan Analisis Regresi Berganda secara komputasi menggunakan SPSS 21. Formula Analisis Regresi Berganda yang digunakan dalam penelitian ini adalah :

$$
Y=a+b_{1} X_{1}+b_{2} X_{2}+b_{3} X_{3}+\varepsilon
$$

di mana:

$\mathrm{Y} \quad=$ Niat Perilaku Pro-Lingkungan

$\mathrm{a} \quad=$ Konstanta

$b_{1} \ldots b_{3}=$ Koefisien variabel $X_{1} \ldots X_{3}$

$\mathrm{X}_{1} \quad=$ Pengetahuan tentang Perubahan Lingkungan

$\mathrm{X}_{2} \quad=$ Persepsi tentang Perubahan Lingkungan

$\mathrm{X}_{3} \quad=$ Sikap terhadap Perubahan Lingkungan

Ketepatan fungsi regresi sampel dalam menaksir nilai aktual dapat diukur dari Goodness of Fit suatu model. Secara statistik, setidaknya ini dapat diukur dari nilai koefisien determinasi $\left(R^{2}\right)$, dan nilai statistik t (Uji t). Perhitungan statistik disebut signifikan secara statistik apabila nilai uji statistiknya berada dalam daerah di mana Ho diterima [14].

Koefisien Determinasi $\left(\mathrm{R}^{2}\right)$ digunakan untuk mengetahui sejauh mana hubungan antara variabel dependen dengan variabel independen atau mengetahui besarnya pengaruh variabel independen terhadap variabel dependen. Semakin dekat nilai $\mathbf{R}^{2}$ ke 1 , makin tepat regresi yang terbentuk untuk meramalkan variabel dependen [14]. Secara matematik, besarnya $R^{2}$ yang disesuaikan didapat dengan persamaan :

$$
K d=r^{2} \times 100 \%
$$

Keterangan:

$\mathrm{Kd} \quad$ : Koefisien determinasi yaitu presentase pengaruh variabel $\mathrm{X}$ terhadap variabel $\mathrm{Y}$.

$\mathrm{R}^{2} \quad$ : Koefisien determinasi. 
Uji Signifikansi Parameter Individual (Uji t) pada dasarnya menunjukan sebarapa jauh pengaruh satu variabel penjelas atau independen secara parsial atau individual dalam menerangkan variasi variabel dependen [14]. Secara matematik, dapat ditulis dengan persamaan [13], sebagai berikut:

$$
\mathrm{T}_{\text {hit }}=\frac{\mathrm{b}-\beta}{\mathrm{sb}}
$$

Keterangan:

$\beta \quad$ : Koefisien Regresi

b : Slope hipotesa

$\mathrm{Sb} \quad$ : Estimasi standar eror

Sedangkan kriteria keputusan (berdasarkan probabilitas) adalah sebagai berikut :

a. Jika t-hitung $>0,05$, maka hipotesis ditolak

b. Jika t-hitung $<0,05$, maka hipotesis diterima

\section{Hasil dan Pembahasan}

\subsection{Karakteristik Responden}

Responden penelitian ini adalah 120 orang yang telah mengisi kuesioner baik secara online maupun offline. Hasil tabulasi menunjukan karakteristik responden menurut jenis kelamin, terdiri dari laki-laki sebanyak 53 orang $(44,17 \%)$ dan perempuan sebanyak 67 orang $(55,83 \%)$.

Selanjutnya karakteristik responden menurut keikutsertaan pada organisasi, responden yang menjadi anggota Pramuka sebanyak 33 orang $(27,50 \%)$, yang menjadi anggota OSIS sebanyak 22 orang (18,33\%), yang menjadi anggota Badan Eksekutif Mahasiswa sebanyak 17 orang (14,17\%), yang menjadi anggota Karang Taruna sebanyak 13 orang (10,87\%), yang menjadi anggota Remaja Mesjid sebannyak 11 orang $(9,17 \%)$, yang menjadi anggota Pemuda Gereja dan Palang Merah Indonesia masing-masing sebanyak 8 orang $(6,67 \%)$, sedangkan selebihnya menjadi anggota Mahasiwa Pencinta Alam dan organisasi lainnya masing-masing sebanyak 4 orang $(3,33 \%)$.

Kemudian karakteristik responden menurut lama menjadi anggota organisasi antara 5-10 tahun sebanyak 66 orang $(55,00 \%)$, yang kurang dari 5 tahun sebanyak 32 orang $(26,67 \%)$ dan selebihnya sebanyak 22 orang $(18,33 \%)$ responden telah menjadi anggota organisasi lebih dari 10 tahun. Karakteristik responden menurut posisi dalam organisasi, sebanyak 82 orang $(68,33 \%)$ sebagai pengurus, sebnyak 37 orang $(30,83 \%)$ sebagai anggota dan selebihnya sebanyak 1 orang $(0,83 \%)$ sebagai relawan.

Sementara itu, karakateristik resonden menurut daerah asal terdiri dari 13 orang $(10,83 \%)$ dari wilayah Sumatera, sebanyak 67 orang $(55,83 \%)$ berasal dari wilayah Jawa, Bali dan Nusa Tenggara, kemudian 19 orang $(15,83 \%)$ berasal dari wilayah Kalimantan dan Sulawesi dan selebihnya sebanyak 21 orang $(17,50 \%)$ berasal dari wilayah Maluku dan Papua.

\subsection{Hasil Uji Kualitas Data}

Hasil pengujian normalitas data penelitian ini menunjukan bahwa data penelitian ini terdistribusi secara normal, yang ditunjukan melalui bentuk kurva distribusi yang berbentuk lonceng. Begitupun dengan grafik normal probability plot memperlihatkan penyebaran titik-titik disekitar garis diagonal dan penyebarannya mengikuti arah garis diagonal.

Hasil pengujian heteroskedastisitas menunjukan tidak ada gejala heteriskedastisitas dari data penelitian ini, yang ditunjukan melalui titik-titik yang menyebar secara acak dan sebarannya berada di atas maupun di bawah angka nol pada sumbu Y. 
Hasil pengujian autokorelasi menunjukan data penelitian ini memiliki gejala autokorelasi positif, di mana nilai DW berada di bawah nilai dL, yang berarti pula bahwa persamaan regresi berganda yang dihasilkan dari penelitian ini tidak bersifat linier. Selanjutnya hasil pengujian multikolinearitas menunjukan tidak adanya gejala multikolinearitas yang ditunjukan melalui nilai VIF yang kurang dari 10. Dari hasil pengujian kualitas data dapat disimpulkan bahwa persamaan regresi yang dihasilkan dari penelitian ini memenuhi kriteria BLUE (best linear unbiased estimate).

\subsection{Hasil Analisis Regresi Berganda}

Ringkasan hasil komputasi data penelitian ini menggunakan SPSS 21 serta dianalisis dengan Regresi Berganda disajikan dalam tabel berikut.

Tabel 1: Hasil Analisis Regresi Berganda

\begin{tabular}{llrrrr}
\hline \multicolumn{1}{c}{ Variabel } & Koefisien Regresi & Std. Error & \multicolumn{1}{c}{ T } & \multicolumn{1}{c}{ Signifikansi } \\
\hline (Constant) & & 3,895 & 0,262 & 6,240 & 0,000 \\
\hline Pengetahuan & & 0,424 & 0,185 & 22,919 & 0,000 \\
\hline Persepsi & 0,652 & 0,013 & 50,154 & 0,000 \\
\hline Sikap & 0,753 & 0,075 & 10,040 & 0,000 \\
\hline R Square & & & & \\
\hline Multiple R & $=0,589$ & & & & \\
\hline
\end{tabular}

Sumber : Hasil perhitungan, 2016

Berdasarkan data pada tabel 1 di atas, dapat dibuat persamaan regresi pengaruh variabel pengetahuan tentang perubahan iklim $\left(\mathrm{X}_{1}\right)$, persepsi tentang perubahan iklim $\left(\mathrm{X}_{2}\right)$, dan sikap terhadap perubahan iklim $\left(\mathrm{X}_{3}\right)$ terhadap niat perilaku pro-lingkungan dari generasi muda $(\mathrm{Y})$ sebagai berikut :

\section{$Y=3,895+0,424 X_{1}+0,652 X_{2}+0,753 X_{3}+0,412$}

Dari persamaan regresi di atas, nilai konstanta sebesar 3,895 satuan menyatakan bahwa jika tidak ada variabel pengetahuan tentang perubahan iklim $\left(\mathrm{X}_{1}\right)$, persepsi tentang perubahan iklim $\left(\mathrm{X}_{2}\right)$, dan sikap terhadap perubahan iklim $\left(\mathrm{X}_{3}\right)$ yang mempengaruhi, maka niat perilaku pro-lingkungan dari generasi muda sudah mempunyai nilai 3,895 yang bersifat konstanta. Sedangkan jika nilai koefisien regresi masing-masing variabel bebas yang diteliti berubah sebesar satu satuan maka niat perilaku prolingkungan akan berubah sebesar nilai faktor tersebut.

Persamaan regresi tersebut menunjukkan bahwa variabel pengetahuan tentang perubahan iklim $\left(\mathrm{X}_{1}\right)$, persepsi tentang perubahan iklim $\left(\mathrm{X}_{2}\right)$, dan sikap teradap perubahan iklim $\left(\mathrm{X}_{3}\right)$ berpengaruh secara positif terhadap niat perilaku pro-lingkungan dari generasi muda, yang ditunjukkan oleh koefisien regresi yang bertanda positif. Ini berarti bahwa setiap kenaikan skor pengetahuan tentang perubahan iklim $\left(\mathrm{X}_{1}\right)$ sebesar satu satuan akan meningkatkan skor niat perilaku pro-lingkungan dari generasi muda (Y) sebesar 0,424 satuan. Demikian juga sebaliknya jika skor variabel pengetahuan tentang perubahan iklim $\left(X_{1}\right)$ mengalami penurunan sebesar satu satuan, akan menurunkan skor niat perilaku pro-lingkungan dari generasi muda $(\mathrm{Y})$ sebesar 0,424 satuan pada taraf signifikansi 0,05 (5\%). Jika dibandingkan dengan sig. 0,000 $<0,05$ maka Ho ditolak atau pengetahuan tentang perubahan iklim berpengaruh secara positif dan signifikan terhadap niat perilaku pro-lingkungan dari generasi muda.

Selanjutnya setiap kenaikan skor variabel persepsi tentang perubahan lingkungan $\left(\mathrm{X}_{2}\right)$ sebesar satu satuan akan meningkatkan skor niat perilaku pro-lingkungan dari generasi muda (Y) sebesar 0,652 satuan. Demikian juga sebaliknya jika skor variabel persepsi tentang perubahan iklim $\left(\mathrm{X}_{2}\right)$ mengalami penurunan sebesar satu satuan, akan menurunkan skor niat perilaku pro-lingkungan dan generasi muda (Y) sebesar 0,652 satuan pada taraf signifikansi 0,05 (5\%). Hasil pengujian menunjukan sig. 0,000 < 0,05 yang berarti Ho ditolak, di mana persepsi tentang perubahan iklim berpengaruh positif dan signifikan terhadap niat perilaku pro-lingkungan dari generasi muda.

Kemudian setiap kenaikan skor variabel sikap terhadap perubahan iklim $\left(\mathrm{X}_{3}\right)$ sebesar satu satuan akan meningkatkan skor niat perilaku pro-lingkungan dari generasi muda (Y) sebesar 0,753 satuan. 
Demikian juga sebaliknya jika skor variabel sikap terhadap perubahan iklim $\left(\mathrm{X}_{3}\right)$ mengalami penurunan sebesar satu satuan, akan menurunkan skor niat perilaku pro-lingkungan (Y) sebesar 0,753 satuan pada taraf signifikansi 0,05 (5\%). Hasil pengujian menunjukan sig.0,000 < 0,05 maka Ho ditolak, artinya sikap terhadap perubahan iklim berpengaruh positif dan signifikan terhadap niat perilaku pro-lingkungan dari generasi muda.

Berdasarkan data pada tabel 1 diketahui Multiple $\mathrm{R}$ adalah koefisien korelasi sebesar 0,767 dan $\mathrm{R}$ square adalah koefisien determinasi yaitu 0,589 yang merupakan pengkuadratan dari koefisien korelasi, sehingga koefisien determinasi menunjukkan bahwa 0,589 niat perilaku pro-lingkungan dari generasi muda $(\mathrm{Y})$ dapat dijelaskan oleh variabel bebas pengetahuan tentang perubahan iklim $\left(\mathrm{X}_{1}\right)$, persepsi tentang perubahan iklim $\left(\mathrm{X}_{2}\right)$, dan sikap terhadap perubahan iklim $\left(\mathrm{X}_{3}\right)$ sebesar 58,9\%, sedangkan sisanya sebesar $41,1 \%$ dijelaskan oleh variabel lain yang tidak termasuk dalam penelitian ini.

Dengan demikian, hasil analisis yang menunjukkan pengaruh variabel pengetahuan tentang perubahan iklim $\left(X_{1}\right)$, persepsi tentang perubahan iklim $\left(X_{2}\right)$, dan sikap terhadap perubahan iklim $\left(X_{3}\right)$ akan meningkatkan niat perilaku pro-lingkungan dari generasi muda (Y) menghasilkan nilai koefisien determinasi sebesar 0,589 berarti bahwa variabel pengetahuan tentang perubahan iklim $\left(\mathrm{X}_{1}\right)$, persepsi tentang perubahan iklim $\left(\mathrm{X}_{2}\right)$, dan sikap teradap perubahan iklim $\left(\mathrm{X}_{3}\right)$ secara simultan dapat menjelaskan 0,589 atau $58,9 \%$ variasi tinggi rendahnya niat perilaku pro-lingkungan dari generasi muda, dan selebihnya sebesar $41,1 \%$ dijelaskan oleh faktor lain yang tidak dimasukkan dalam penelitian ini.

Pengujian hipotesis penelitian ini menunjukan bahwa :

Hipotesis ke-1 diterima, di mana pengetahuan tentang perubahan iklim berpengaruh secar apositif dan signifikan terhadap niat perilaku pro-lingkungan dari generasi muda, yang ditunjukan melalui nilai $t$ hitung $(22,919)$ yang lebih besar dari nilai t tabel $(2,62)$ dengan signifikansi 0,000 . Selanjutnya hipotesis ke-2 juga diterima, di mana persepsi tentang perubahan iklim berpengaruh positif dan signifikan terhadap niat perilaku pro-lingkugan dari generasi muda, yang ditunjukan melalui nilai $\mathrm{t}$ hitung $(50,154)$ yang lebih besar dari nilai $t$ tabel $(2,62)$. Demikian pula hipotesis ke-3 yang diajukan dalam penelitian ini dapat diterima, di mana sikap terhadap perubahan iklim berpengaruh positif dan signifikan terhadap niat perilaku pro-lingkungan dari generasi muda. Selanjutnya, dari ketiga variabel bebas tersebut, variabel persepsi memiliki nilai t hitung yang terbesar, dengan demikian hipotesis ke-4 yang diajukan dalam penelitian ini dapat diterima, di mana persepsi tentang perubahan iklim merupakan faktor yang memiliki pengaruh paling dominan terhadap niat perilaku pro-lingkungan dari generasi muda.

\section{Pembahasan}

Hasil penelitian ini menunjukan bahwa faktor pengetahuan, persepsi dan sikap tentang perubahan iklim memiliki pengaruh yang positif dan signifikan terhadap niat perilaku pro-lingkungan dari generasi muda. Selanjutnya persepsi tentang perubahan iklim merupakan faktor yang paling berpengaruh terhadap niat perilaku pro-lingkugan dari generasi muda.

Hasil penelitian ini sejalan dan mendukung beberapa hasil penelitian terdahulu, seperti Worsley and Skrzypiec (1998) yang mengeksplorasi sikap dari siswa sekolah menengah di 32 negara, di mana mereka menemukan bahwa sebagian besar pelajar memiliki perhatian terhadap isu-isu lingkungan. Demikian juga Connell et al. (1999) yang melakukan penelitian tentang sikap terhadap lingkungan dari generasi muda di Australia, di mana hasilnya menunjukan adanya pertentangan antara kepedulian terhadap lingkungan dan sikap pesimis dari generasi muda. Selanjutnya Blanchet-Cohen, Ragan, dan Amsden (2003) juga telah melakukan pemetaan visual tentang isu-isu lingkungan di kalangan anak sekolah, yang menghasilkan sepuluh tema terkait isu linkungan, yakni inisiatif, pernyataan nilai, pemikiran, afektif, perlakuan, kebijakan, pilihan gaya hidup, kesadaran edukasi, berhenti melakukan dan kejelekan. Selain itu, . Meinhold and Malkus (205) melakukan studi tentang hubungan antara perilaku terkiat lingkungan dari kaum muda, efikasi diri, pengetahuan dan sikap. Hasilnya menunjukan bahwa nurani berpengaruh terhadap sikap pro-lingkungan. Penelitian mereka juga 
menemukan bahwa pengetahuan merupakan faktor pemoderasi yang signifikan untuk sikap prolingkungan, serta efikasi diri memiliki pengaruh yang positif terhadap sikap pro-lingkungan dari generasi muda. Selanjutnya, Hicks and Holden (2007) telah melakukan sebuah penelitian yang menemukan bahwa siswa sekolah yang berusia di bawah 14 tahun membutuhkan lebih banyak kenyamanan, perumahan yang terjangkau, hubungan yang lebih baik antar penduduk, rendahnya kejahatan dan kriminal di komunitas lokal mereka. Sedangkan siswa sekolah yang berusia 14-18 tahun lebih memberi perhatian terhadap kemiskinan, pengangguran dan berbagai permasalahan lingkungan. Demikian pula Boeve-de Pauw and Van Petegem (2010) telah menganalisis sikap terhadap lingkungan dari kaum muda di 56 negara. Hasil analisis mereka menunjukan bahwa pada tingkatan individual kaum muda memiliki sikap terhadap lingkungan yang dipengaruhi oleh gender, latar belakang sosioekonomi, kebudayaan dan sumberdaya pendidikan. Sementara pada level negara, hasil penelitian mereka menunjukan pentingnya faktor kekayaan sumber daya alam dari suatu negara dan permasalahan lingkungan dari negara tersebut terhadap pembentukan sikap pro-lingkungan dari kaum mudanya.

Hasil penelitian ini menunjukan bahwa untuk menumbuhkan kesadaran bagi generasi muda tentang perubahan iklim dan dampaknya bagi kelangsungan hidup manusia, perlu dilakukan berbagai upaya yang konstruktif dalam memberikan pengetahuan tentang isu-isu lingkungan, terutama yang terkait dengan perubahan iklim. Pengetahuan yang diberikan bagi generasi muda dapat dilakukan melalui berbagai saluran dan sumber informasi seperti website, media sosial, dan sebagainya.dengan pengetahuan yang dimiliki, akan membentuk persepsi mereka yang lebih baik tentang perubahan iklim, yang pada gilirannya akan membentuk sikap mereka. Denan pengetahuan yang dimiliki, generasi muda akan lebih memahami tentang perubahan iklim dan berbagai isu lingkungan lainnya. Hal ini menjadi penting karena hasil penelitian ini menunjukan bahwa persepsi tentang perubahan iklim memiliki pengaruh yang lebih dominan terhadap niat mereka untuk berperilaku pro-lingkungan. Demikian pula pemanfaatan organisasi tempat mereka berkecimpung sebagai sarana untuk menggugah kepedulian dan mendorong peran serta generasi muda dalam ikut terlibat mengatasi permasalahanpermasalahan lingkungan yang terkait dengan perubahan iklim.

\section{Kesimpulan}

Penelitian ini bertujuan untuk menganalisis pengaruh dari faktor pengetahuan, persepsi dan sikap tentang perubahan iklim terhadap niat perilaku pro-lingkungan dari generasi muda. Hasilnya menunjukan bahwa faktor pengetahuan, persepsi dan sikap tentang perubahan iklim memiliki pengaruh yang positif dan signifikan terhadap niat perilaku pro-lingkugan dari generasi muda, serta faktor persepsi memiliki pengaruh yang lebih dominan terhadap niat perilaku pro-lingkungan dan generasi muda.

Dengan demikian, untuk lebih menumbuh-kembangkan niat generasi muda untuk berperilaku yang pro-lingkungan, bagi mereka perlu diberikan kesempatan dan akses yang lebih luas teradap sumber dan jalur informasi untuk menambah pengetahuan terkait isu-isu lingkungan yang strategis, terutama perubahan iklim dan dampaknya, sehingga dengan pengetahuan tersebut akan membentuk persepsi mereka yang lebih baik tentang perubahan iklim dan pada gilirannya akan membentuk sikap yang lebih berempati terhadap perubahan iklim.

Untuk itu, salah satu cara yang dapat digunakan adalah dengan memberdayakan organisasi tempat mereka berkecimpung sebagai sarana untuk menambah pengetahuan, membentuk persepsi dan sikap serta menggugah niat mereka untuk berperilaku yang pro-lingkungan, melalui akivitas yang teratur, terarah dan terencana.

\section{DAFTAR Pustaka}

Surna Tjahja Djajadiningrat, Yeni Hendriani dan Melia Famiola (2014) 'Green Economy (Ekonomi), Edisi Revisi, Bandung : Rekayasa Sains

https://id.wikipedia.org/wiki/Perubahan_iklim, diakses 15 Oktober 2016

Diamantopoulos, A., Schlegelmilch, B. B., Sinkovics, R. R., \& Bohlen, G. M. (2003) Can sociodemographics still play a role in profiling green consumers? A review of the evidence and an empirical investigation, Journal of Business Research, 56(6), pp. 465-480. 
Boeve-de Pauw, J., \& Van Petegem, P. (2010) ‘A cross-national perspective on youth environmental attitudes', The Environmentalist, 30(2), pp. 133-144.

Wesley, M. (2011) 'Environmental opinion in today's society', Carthage College, Kenosha, WI 53140.

Ancok, D. 1997. Teknik Penyusunan Skala Pengukuran. Pusat Penelitian Kependudukan Universitas Gadjah Mada. Yogyakarta.

Notoatmodjo, S. (2003) 'Pendidikan dan Perilaku Kesehatan' Jakarta : Rineka Cipta.

Azwar, S. (2008) 'Seri Psikologi, Sikap Manusia, Teori dan Pengukurannya' Yogyakarta : Liberty

Purwanto (1998) 'Pengantar Perilaku Manusia untuk Keperawatan' Cetakan I, Jakarta : EGC

Notoatmodjo, S. (2005) 'Promosi Kesehatan (Teori dan Aplikasi)' Jakarta : Rineka Cipta

Ajzen, Icek (1988) 'Attitudes, Personality, and Behavior', Milton-Keynes, England: Open University Press \& Chicago, IL: Dorsey Press.

Schiffman, L.G and Kanuk, L.L (2000) 'Consumer Behavior', Seventh Edition, New Jersey : Prentice Hall Inc.

Suliyanto (2011) 'Ekonometrika Terapan : Teori dan Aplikasi dengan SPSS', Yogyakarta : Penerbit Andi

Imam Ghozali, (2001) 'Analisis Multivariate dengan Program SPSS', Semarang : Badan Penerbit Universitas Diponegoro

Worsley, A., and Skrzypiec, G. (1998) 'Environmental attitudes of senior secondary school students in South Australia', Global Environmental Change, 8(3), pp. 209-225.

Connell, S., Fien, J., Lee, J., Sykes, H., and Yencken, D. (1999) 'If it doesn't directly affect you, you don't think about it': A qualitative study of young people's environmental attitudes in two Australian cities', Environmental Education Research, 5(1), pp. 95-113.

Blanchet-Cohen, N., Ragan, D., \& Amsden, J. (2003), 'Children becoming social actors: Using visual maps to understand children's views of environmental change, Children Youth and Environments, 13(2), pp. 278-299.

Meinhold, J. L., and Malkus, A. J. (2005) 'Adolescent Environmental Behaviors Can Knowledge, Attitudes, and SelfEfficacy Make a Difference?’ Environment and Behavior, 37(4), pp. 511-532.

Hicks, D., and Holden, C. (2007) 'Remembering the future: what do children think?', Environmental Education Research, 13(4), pp. 501-512.

Boeve-de Pauw, J., \& Van Petegem, P. (2010) 'A cross-national perspective on youth environmental attitudes', The Environmentalist, 30(2), pp. 133-144. 
SPECTA Journal of Technology, Vol. 1, No. 3, November-December 2017 ISSN : 2549-2713 